\title{
Polyacrylamide Gel Electrophoresis Analysis of Ribosomal Protein AT-L30 from an Actinomycete Genus, Streptosporangium
}

\author{
$\mathrm{KOZO} \mathrm{OCHI}^{1 *}$ AND SHINJI MIYADOH ${ }^{2}$ \\ National Food Research Institute, 2-1-2 Kannondai, Tsukuba, Ibaraki $305^{1}$ and \\ Pharmaceutical Research Center, Meiji Seika Kaisha, Ltd., Morooka, \\ Kohoku-ku, Yokohama 222, ${ }^{2}$ Japan
}

\begin{abstract}
We analyzed the ribosomal AT-L30 proteins from 11 type strains of species belonging to the genus Streptosporangium. The electrophoretic mobilities of the AT-L30 preparations from these strains, as determined by two-dimensional polyacrylamide gel electrophoresis, revealed that they could be divided into three groups. The first group contained Streptosporangium viridogriseum, $S$. viridogriseum subsp. kofuense, and $S$. albidum, while the second group contained $S$. roseum, $S$. album, $S$. vulgare, $S$. nondiastaticum, $S$. fragile, $S$. violaceochromogenes, and $S$. amethystogenes. $S$. corrugatum was a member of the third group. These groups were completely consistent with Nonomura's previous classification, which was based on morphological criteria. The results of partial amino acid sequencing of AT-L30 preparations from several representative strains strongly supported the hypothesis that each of the three groups of the genus Streptosporangium merits separate generic status.
\end{abstract}

In previous publications, Ochi and coworkers have begun to explore the phylogenetic relationships among groups of actinomycetes as determined by ribosomal protein AT-L30 analysis (14-17). This method depends on the heterogeneity of ribosomal AT-L30 proteins among genera of actinomycetes. Analysis of AT-L30 proteins by two-dimensional polyacrylamide gel electrophoresis (PAGE) has been used successfully to establish the taxonomic status of the genera Actinomadura and Microtetraspora (16). Subsequently, the taxonomic status of representatives of the validly described genera classified in the family Pseudonocardiaceae has been determined by analyzing of their AT-L30 proteins (17). Analysis of AT-L30 proteins by two-dimensional PAGE has also been used successfully to investigate the taxonomic status of the genera Nocardia, Rhodococcus, Tsukamurella, and Gordona (15). In this study, we used our PAGE analysis method to examine the taxonomy of the genus Streptosporangium.

The term maduromycetes was first introduced by Goodfellow and Cross (5) for a member of poorly circumscribed sporoactinomycetes that have a number of chemical and morphological features in common (4). The maduromycetes currently include the sporangiate genera Streptosporangium, Planobispora, and Planomonospora, as well as the oligosporic genus Microbispora and the revised genus $\mathrm{Mi}$ crotetraspora $(3,11)$. Goodfellow et al. recently proposed that this term could also accommodate organisms that are assigned to the new family Streptosporangiaceae (6). These organisms contain meso-diaminopimelic acid and madurose (3-O-methyl-D-galactose) in their whole-cell hydrolysates. Among the genera of maduromycetes, the genus Streptosporangium is characterized by a distinctive morphological property (i.e., formation of spore vesicles containing numerous nonmotile spores). Interestingly, as described by Nonomura (13), the members of the genus Streptosporangium can be divided into three groups on the basis of their morphological characteristics. Group 1 is characterized by thick, strong spore vesicle walls and contains Streptosporangium viridogriseum, Streptosporangium viridogriseum subsp.

\footnotetext{
* Corresponding author.
}

kofuense, and Streptosporangium albidum. Group 2 is characterized by thin, fragile spore vesicle membranes and contains Streptosporangium album, Streptosporangium amethystogenes, Streptosporangium longisporum, Streptosporangium nondiastaticum, Streptosporangium pseudovulgare, Streptosporangium roseum, Streptosporangium violaceochromogenes, Streptosporangium viridialbum, Streptosporangium vulgare, and Streptosporangium fragile. Group 3 is characterized by small spore vesicles; Streptosporangium corrugatum belongs to this morphological group. The aim of this study was to clarify the taxonomic status of these three groups as determined by ribosomal AT-L30 protein analysis.

\section{MATERIALS AND METHODS}

Bacterial strains. The strains which we used are listed in Table 1. All of the organisms were type strains that were obtained from the Japan Collection of Microorganisms, Saitama, Japan, the Institute of Fermentation, Osaka, Japan, and the American Type Culture Collection, Rockville, Md. The strains were grown to mid-exponential phase in soluble starch-Polypeptone-yeast extract medium (14) at $30^{\circ} \mathrm{C}$ for 20 to $40 \mathrm{~h}$.

Two-dimensional PAGE. Ribosomal proteins were prepared from $70 S$ ribosomes by extraction with acetic acid, as previously described (14), using the method of Hardy et al. (7). For PAGE, the method of Kaltschmidt and Wittmann (10) was used, as described previously (14). The gels were run two to three times for each ribosomal protein sample to confirm the reproducibility of the results obtained.

Determination of amino acid sequence. When we were preparing the AT-L30 protein samples for amino acid sequence analysis, we applied large amounts ( 2 to $3 \mathrm{mg}$ ) of the total ribosomal proteins to the PAGE gels. After twodimensional PAGE, the spots (containing about $50 \mu \mathrm{g}$ of protein) assigned to AT-L30 protein were cut from the gels The proteins were extracted from the gels by electrophoresis with a model TB-8 blotting cell (TEFCO) as described below. (Although we originally described a washing procedure for removing the pigment from the cut gel [16], this procedure was later omitted since we found that the pigment 
TABLE 1. Electrophoretic mobilities of ribosomal AT-L30 proteins from the type strains of the members of the genus Streptosporangium

\begin{tabular}{|c|c|c|}
\hline Strain & $\begin{array}{c}\text { Mobility of } \\
\text { AT-L30 } \\
(\mathrm{mm})^{a}\end{array}$ & $\mathbf{R E M}^{b}$ \\
\hline Streptosporangium corrugatum JCM $3181^{\mathrm{T} c}$ & 2.0 & 3.0 \\
\hline Streptosporangium album JCM $2177^{\mathrm{T}}$ & 14.5 & 21.0 \\
\hline Streptosporangium roseum JCM $2178^{\mathrm{T}}$ & 14.5 & 21.0 \\
\hline Streptosporangium vulgare JCM $3082^{\mathrm{T}}$ & 15.7 & 23.0 \\
\hline Streptosporangium nondiastaticum JCM $3114^{\mathrm{T}}$ & 17.1 & 25.0 \\
\hline Streptosporangium fragile IFO $14311^{\mathrm{T}}$ & 17.8 & 26.0 \\
\hline $\begin{array}{l}\text { Streptosporangium violaceochromogenes } \\
\text { JCM } 3281^{\mathrm{T}}\end{array}$ & 20.0 & 29.0 \\
\hline Streptosporangium amethystogenes JCM $3026^{\mathrm{T}}$ & 21.0 & 30.5 \\
\hline Streptosporangium viridogriseum JCM $3282^{\mathrm{T}}$ & 34.6 & 50.5 \\
\hline Streptosporangium albidum IFO $13901^{\mathrm{T}}$ & 35.0 & 51.0 \\
\hline $\begin{array}{l}\text { Streptosporangium viridogriseum subsp. kofuense } \\
\text { JCM } 3157^{\mathrm{T}}\end{array}$ & 45.7 & 66.5 \\
\hline Kibdelosporangium aridum ATCC $39323^{\mathrm{T}}$ & 28.6 & 41.5 \\
\hline Saccharomonospora viridis JCM $3036^{\mathrm{T}}$ & 68.5 & 100 \\
\hline
\end{tabular}

${ }^{a}$ Mobility of the AT-L30 protein in the first dimension.

${ }^{b}$ The mobility of protein AT-L30 from Saccharomonospora viridis JCM $3036^{\mathrm{T}}$ was defined as unity $(100)$.

${ }^{c} \mathrm{~T}=$ type strain.

had no effect on the amino acid sequence.) Electrophoresis was carried out for $24 \mathrm{~h}$ at a constant current of $300 \mathrm{~mA}$ (initial voltage, $8 \mathrm{~V}$ ); the protein was extracted from each gel on a membrane (ProBlott; Applied Biosystems, Foster City, Calif.), which was placed on the cathode side. The buffer solution which we used contained (per liter) $300 \mathrm{~g}$ of urea, 14 $\mathrm{g}$ of glycine, and $52 \mathrm{ml}$ of acetic acid (adjusted to $\mathrm{pH} 4$ by 5 $\mathrm{N} \mathrm{KOH}$ ). Sequence analyses of the extracted proteins were performed with a model 470A protein sequencer (Applied Biosystems).

\section{RESULTS AND DISCUSSION}

Two-dimensional PAGE analysis of ribosomal proteins. The ribosomal proteins of 11 species of the genus Streptosporangium were extracted with acetic acid and separated by two-dimensional PAGE. The results obtained for several species are shown in Fig. 1. When we compared the ribosomal protein patterns, it was immediately evident that some of the spots (Fig. 1, arrows) were homologous proteins. These proteins were designated AT-L30 proteins because of their amino acid sequence homology (see below). The results for Saccharomonospora viridis, whose AT-L30 protein was defined as unity for determining relative electrophoretic mobilities (REMs), are shown in Fig. 1F. Figure 1 shows that the electrophoretic mobilities of the AT-L 30 proteins in the first dimension of gel electrophoresis differed among the species examined. The distances that the AT-L30 proteins moved in the first dimension in the original slab gels are shown in Table 1. Table 1 also shows the electrophoretic mobility of the AT-L30 protein from each species relative to the electrophoretic mobility of Saccharomonospora viridis AT-L30 protein, which exhibited the greatest mobility among all of the AT-L30 proteins from actinomycetes examined so far (15). The experimental error for the REM defined in this way was at most $5 \%$, as determined by several gel runs of the same sample. Table 1 shows that the species which we tested could be divided into three clusters; cluster 1 species (REM, 3.0) exhibited slight AT-L30 protein mobility in the first dimension of gel electrophoresis, and in cluster
2 species (REMs, 21.0 to 30.5 ) and cluster 3 species (REMs, 50.5 to 66.5 ) the AT-L 30 proteins migrated to the cathode side (the right side in Fig. 1). The clustering is also shown in Fig. 2. Streptosporangium corrugatum was a member of cluster 1. Cluster 2 contained Streptosporangium album, Streptosporangium roseum, Streptosporangium vulgare, Streptosporangium nondiastaticum, Streptosporangium fragile, Streptosporangium violaceochromogenes, and Streptosporangium amethystogenes, while cluster 3 contained Streptosporangium viridogriseum, Streptosporangium viridogriseum subsp. kofuense, and Streptosporangium albidum. It was striking that this clustering was completely consistent with the morphological classification of Nonomura (13). Since the genera of actinomycetes have been shown to have REMs that are specific for each genus (15-17), it seems reasonable to propose that the genus Streptosporangium is an assembly of phylogenetically distinct taxa. To examine this idea, we determined the amino acid sequences of the AT-L30 proteins from several species.

Amino acid sequences of the AT-L30 proteins. As Fig. 3 shows, a highly homologous sequence (indicated by underlining) was found in Escherichia coli and the three species of Streptosporangium examined. These results provide strong evidence that the AT-L30 proteins in the Streptosporangium species which we tested are homologous to protein L30 of $E$. coli. Furthermore, a comparison of the sequence of each AT-L30 protein with the known sequences of $E$. coli ribosomal proteins other than the L30 protein showed no homology at all. Thus, it was evident that we were indeed dealing with the proteins (designated AT-L30 proteins) that are homologous to protein L 30 of $E$. coli.

It should be noted that the amino acid sequences of the AT-L30 proteins of Streptosporangium roseum and Streptosporangium amethystogenes, members of cluster 2 , exhibited an extremely high level of homology; in contrast, there was less homology between Streptosporangium viridogriseum subsp. kofuense and these two organisms (Fig. 3). To express quantitatively the level of similarity of the amino acid sequences (SAS values), we determined the frequency of appearance of the same amino acid in $20 \mathrm{~N}$-terminal amino acids of each AT-L30 protein. The SAS values determined in this way are shown in Table 2 . We found that the species belonging to the same genus had very high SAS values ( 90 to $100 \%$ ), as exemplified by three species of the genus $M i$ crotetraspora. On the other hand, species belonging to different genera exhibited low SAS values (20 to $62 \%$ ). We also evaluated the SAS values determined for species of the genus Streptosporangium. As expected from the REM results, the SAS value for Streptosporangium roseum and Streptosporangium amethystogenes was high $(94 \%)$, indicating that these two species should be viewed as a single taxon. In contrast, the SAS values for Streptosporangium viridogriseum subsp. kofuense and Streptosporangium roseum or Streptosporangium amethystogenes were significantly lower ( 76 and $71 \%$, respectively). These SAS values are closer to the values observed for different genera than the values observed for members of the same genus. These results, together with the marked differences in REMs (Fig 2), provide phylogenetic evidence that the species in group 1 of Nonomura (e.g., Streptosporangium viridogriseum subsp. kofuense) and those in group 2 (e.g., Streptosporangium roseum) are separable at the generic level. Also, although amino acid sequencing was not conducted, group 3 (e.g., Streptosporangium corrugatum) should be considered an independent taxon that is separable from groups 1 and 2 on the basis of the remarkable differences in their REMs 


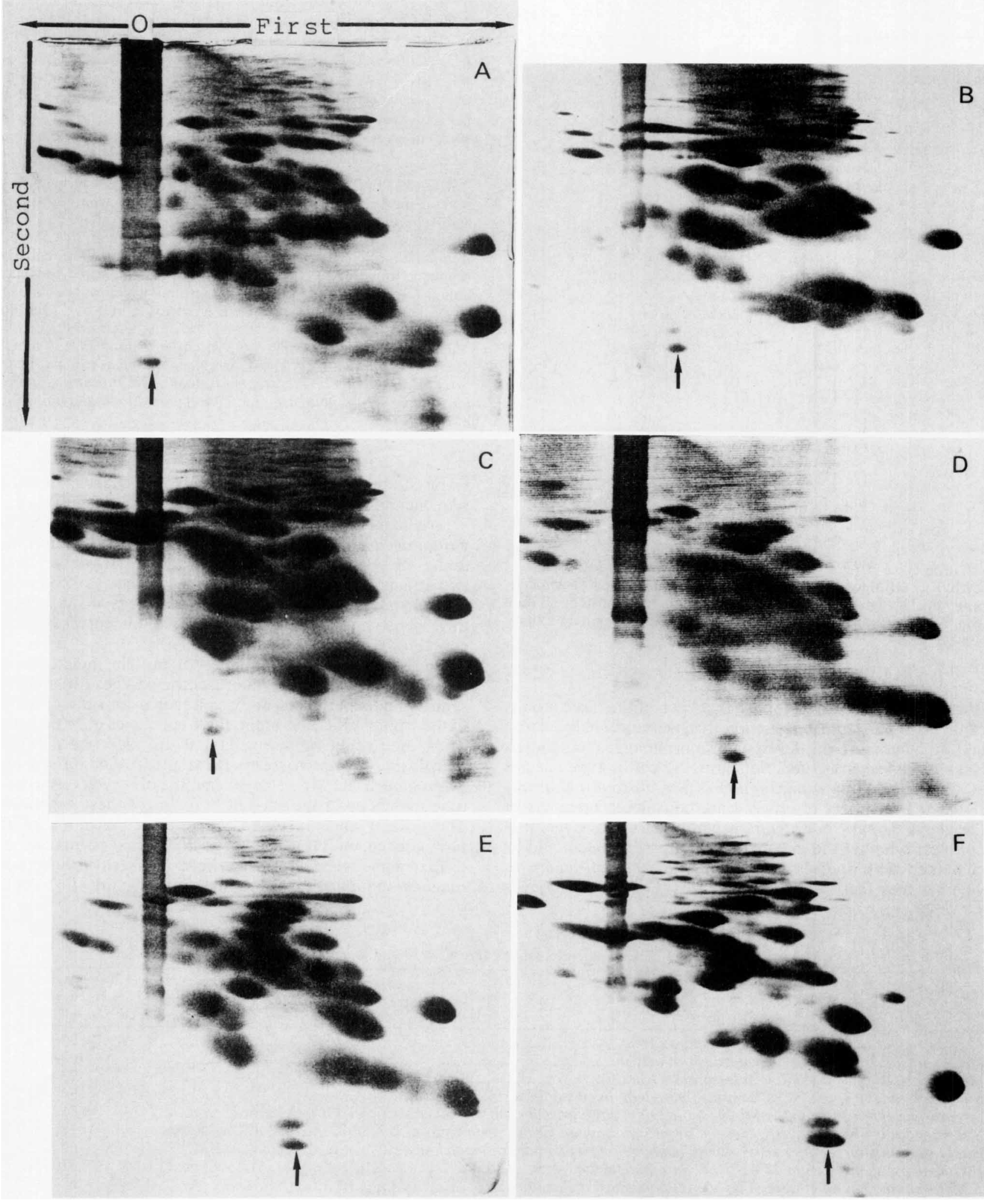

FIG. 1. Two-dimensional PAGE of total ribosomal proteins from members of the genus Streptosporangium. The gel system was based on the system of Kaltschmidt and Wittmann (10). The $O$ in panel A indicates the origin in the first dimension. The arrows indicate the positions of AT-L30 proteins. (A) Streptosporangium corrugatum. (B) Streptosporangium roseum. (C) Streptosporangium amethystogenes. (D) Streptosporangium viridogriseum. (E) Streptosporangium viridogriseum subsp. kofuense. (F) Saccharomonospora viridis. 


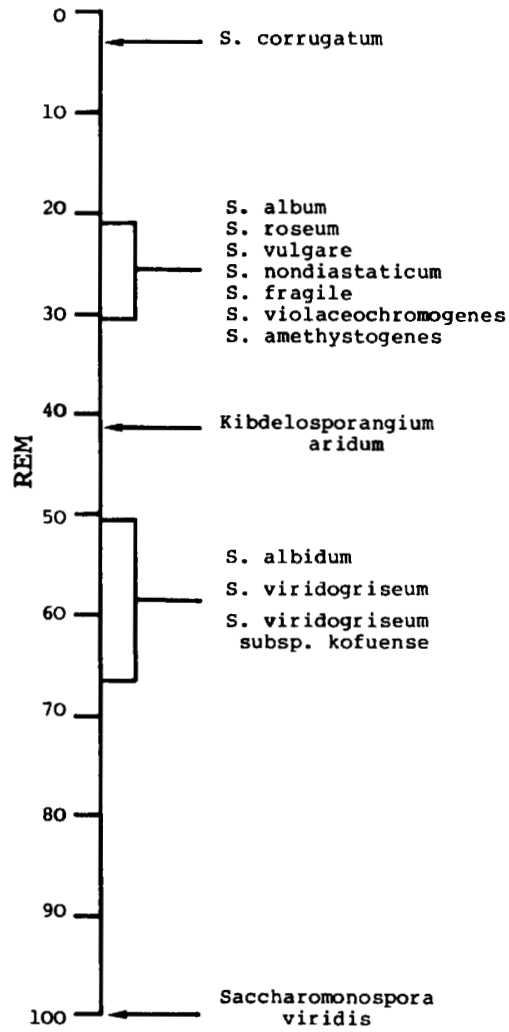

FIG. 2. REM values for the members of the genus Streptosporangium. The data are from Table 1 . The mobility of protein AT-L30 from Saccharomonospora viridis JCM $3036^{\mathrm{T}}$ was defined as unity (100).

(Fig. 2). Therefore, we propose that each of the three groups of the genus Streptosporangium that were originally classified by Nonomura on the basis of morphological characteristics merits separate generic status. Since the type species of the genus Streptosporangium is Streptosporangium roseum, the members of group 2 are considered members of the genus Streptosporangium sensu stricto. However, it is not clear whether the members of groups 1 and 3 should be combined with species of previously described genera or whether they merit new generic status. Our proposal needs

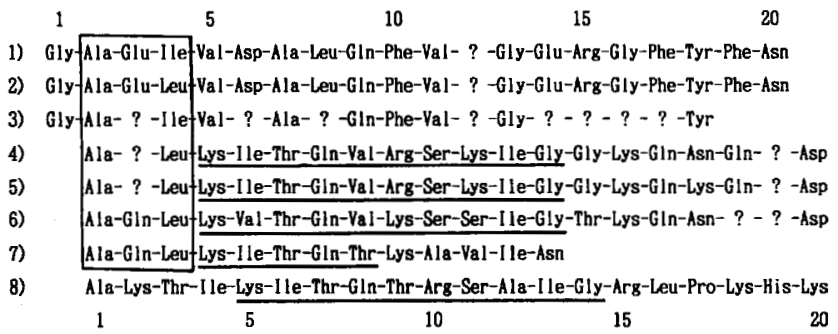

FIG. 3. Primary structures of $\mathrm{N}$ termini of AT-L30 proteins from several species of the genera Streptosporangium, Microtetraspora, and Actinomadura. The data for $E$. coli are from reference 18 , and the data for Microtetraspora glauca, Microtetraspora helvata, and Actinomadura malachitica are from reference 16. The common sequence found in $E$. coli and other strains is indicated by underlining. A sequence signature in the $\mathrm{N}$ termini, which was common to all of the actinomycetes examined, is enclosed in a box. Question marks indicate amino acids that were not determined. Line 1 , Microtetraspora glauca; line 2, Microtetraspora fusca; line 3, Microtetraspora helvata; line 4, Streptosporangium roseum; line 5, Streptosporangium amethystogenes; line 6, Streptosporangium viridogriseum subsp. kofuense; line 7, Actinomadura malachitica; line 8, E. coli K-12.

to be studied by using other approaches, such as rRNA sequencing, DNA relatedness, or chemotaxonomy.

Streptosporangium viridogriseum and Streptosporangium viridogriseum subsp. kofuense exhibited considerably different REMs (50.5 versus 66.5) (Table 1). However, these two strains can be assigned to a single species or to closely related species since there was a great deal of similarity in their ribosomal protein patterns on two-dimensional PAGE gels (Fig. 1D and E).

The electrophoretic mobilities of protein molecules are greatly affected by the level of electric charge. Although the sequencing experiments were conducted for only one-third of the whole AT-L30 protein, the frequencies of basic amino acids and acidic amino acids in E. coli (REM, 73.0), Streptosporangium roseum (REM, 21.0), and Microtetraspora glauca (REM, -5.0) explain the observed electrophoretic mobilities of the AT-L30 proteins of these organisms. Thus, REM appears to be an accurate reflection of the physicochemical properties of each AT-L30 protein.

Taxonomic relationship between the genus Streptosporangium and allied taxa. Previous investigations have dem-

TABLE 2. Comparisons among the AT-L30 amino acid sequences

\begin{tabular}{|c|c|}
\hline Strains compared & $\begin{array}{l}\text { Level of similarity of amino } \\
\text { acid sequences } \\
\text { (SAS value) }(\%)^{a}\end{array}$ \\
\hline Microtetraspora glauca vs Microtetraspora fusca .. & 94 \\
\hline Microtetraspora glauca vs Microtetraspora helvata..... & 100 \\
\hline Microtetraspora fusca vs Microtetraspora helvata ............................ & 90 \\
\hline 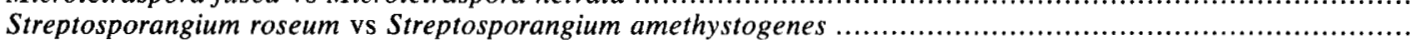 & 94 \\
\hline Streptosporangium roseum vs Streptosporangium viridogriseum subsp. kofuense ............... & 76 \\
\hline 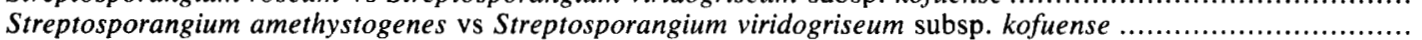 & 71 \\
\hline 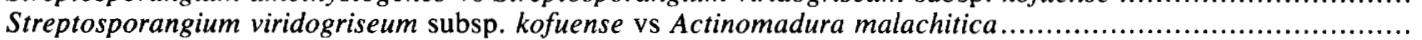 & 62 \\
\hline 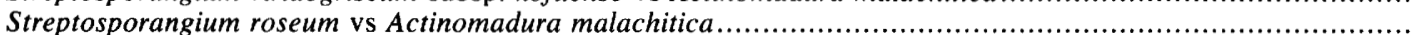 & 58 \\
\hline 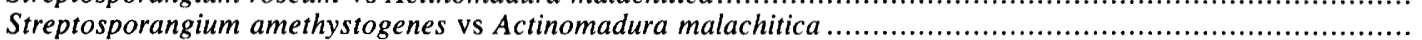 & 58 \\
\hline 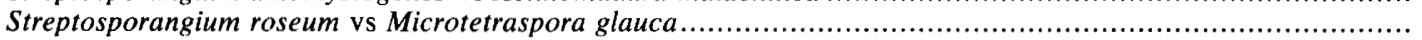 & 20 \\
\hline 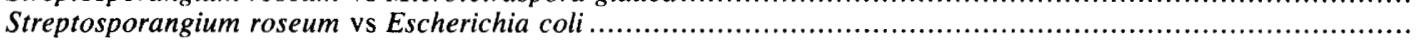 & 47 \\
\hline 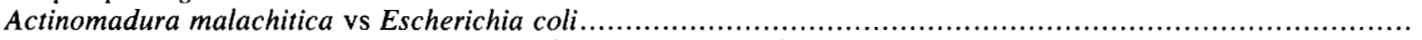 & 46 \\
\hline 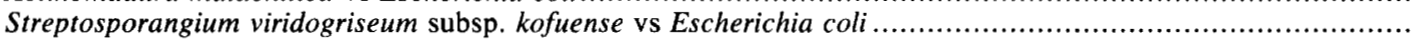 & 35 \\
\hline
\end{tabular}

${ }^{a}$ The SAS value for each pair of organisms for $20 \mathrm{~N}$-terminal amino acids of the AT-L30 proteins was determined on the basis of the data shown in Fig. 3. 
onstrated that the genus Streptosporangium is more closely related to the genus Microtetraspora than to the genus Actinomadura, as shown by the results of $16 \mathrm{~S}$ rRNA analyses and by chemotaxonomic characteristics $(1,2,12)$. In contrast, our ribosomal AT-L30 protein analyses provided the opposite result; namely, the SAS value observed for Streptosporangium roseum and Actinomadura malachitica was much higher than that observed for Streptosporangium roseum and Microtetraspora glauca (58 versus $20 \%$ ) (Table 2). Furthermore, the REMS for the genus Streptosporangium sensu stricto (21.0 to 30.5 ) were closer to the REMs for the genus Actinomadura (14.0 to 41.5) than the REMs for the genus Microtetraspora ( -6.5 to 0 ) (see reference 16). Ribosomal proteins and rRNA are both components of ribosomes, whose variability is considered to be more limited than that of the other cellular components because of many structural and functional constraints $(8,9)$. Therefore, it is surprising that analyses of ribosomal proteins and rRNAs led to different conclusions, but this may imply that molecular evolution of ribosomal proteins and molecular evolution of rRNAs proceed independently. The apparent incongruity between the protein and rRNA data is fascinating and does underline the importance of basing phylogenetic relationships on more than one type of molecule. However, it does seem likely that in this case the true relationships are those that are based on nucleotide sequences given the excellent agreement with the chemotaxonomic data. It is well known that ribosomal proteins have evolved at very different rates, depending on the individual proteins and their functions (21). The genus Microtetraspora appears to occupy an isolated position in the evolution of maduromycetes, since the amino acid sequence of the ATL30 proteins from this genus was especially different from the other amino acid sequences (Fig. 3). It is noteworthy that Streptosporangium corrugatum, a member of group 3 of the genus Streptosporangium, had an REM (3.0) that was similar to the REMs for the genus Microtetraspora ( -6.5 to 0 ). This fact implies a close phylogenetic relationship between Streptosporangium corrugatum and the genus Microtetraspora, but a comparison on the level of amino acid sequence is required to establish the taxonomic relationship of these organisms.

The genus Kibdelosporangium was recently described by Shearer et al. (20). Morphologically, this genus closely resembles group 1 Streptosporangium species, but it has cell wall chemotype IV (19). Our results supported the previous proposal of Shearer et al., since the REM for Kibdelosporangium aridum ATCC $39323^{\mathrm{T}}$ did not fall within the REM ranges observed for the Streptosporangium groups (Fig. 2).

The novel method discussed above will contribute to polyphasic taxonomy of actinomycete taxa, especially when it is used together with $16 \mathrm{~S}$ rRNA analysis.

\section{ACKNOWLEDGMENT}

We thank Eriko Satoh for her skilled assistance in determining amino acid sequences.

\section{REFERENCES}

1. Fischer, A., R. M. Kroppenstedt, and E. Stackebrandt. 1983 Molecular-genetic and chemotaxonomic studies on Actinomadura and Nocardiopsis. J. Gen. Microbiol. 129:3433-3446.

2. Fowler, V. J., W. Ludwig, and E. Stackebrandt. 1985. Ribosomal ribonucleic acid cataloguing in bacterial systematics: the phylogeny of Actinomadura, p. 17-40. In M. Goodfellow and D. E. Minnikin (ed.), Chemical methods in bacterial systemat- ics. Academic Press, London.

3. Goodfellow, M. 1989. Suprageneric classification of actinomycetes, p. 2333-2339. In S. T. Williams, M. E. Sharpe, and J. G. Holt (ed.), Bergey's manual of systematic bacteriology, vol. 4. The Williams \& Wilkins Co., Baltimore.

4. Goodfellow, M. 1989. Maduromycetes, p. 2509-2551. In S. T. Williams, M. E. Sharpe, and J. G. Holt (ed.), Bergey's manual of systematic bacteriology, vol. 4. The Williams \& Wilkins Co., Baltimore.

5. Goodfellow, M., and T. Cross. 1984. Classification, p. 7-164. In M. Goodfellow, M. Mordarski, and S. T. Williams (ed.), The biology of the actinomycetes. Academic Press, London.

6. Goodfellow, M., L. J. Stanton, K. E. Simpson, and D. E. Minnikin. 1990. Numerical and chemical classification of Actinoplanes and some related actinomycetes. J. Gen. Microbiol. 136:19-36.

7. Hardy, S. J. S., C. G. Kurland, P. Voynow, and G. Mora. 1969. The ribosomal proteins of Escherichia coli. I. Purification of the 30S ribosomal proteins. Biochemistry 8:2897-2905.

8. Hori, H., K. Higo, and S. Osawa. 1977. The rates of evolution in some ribosomal components. J. Mol. Evol. 9:191-201.

9. Hori, H., B. L. Lim, T. Ohama, T. Kumazaki, and S. Osawa. 1985. Evolution of organisms deduced from 5S rRNA sequences, p. 324-335. In T. Ohta and K. Aoki (ed.), Population genetics and molecular evolution. Japan Scientific Society Press/Elsevier, Tokyo.

10. Kaltschmidt, E., and H. G. Wittmann. 1970. Ribosomal proteins. VII. Two-dimensional polyacrylamide gel electrophoresis analysis for finger-printing of ribosomal proteins. Anal. Biochem. 36:401-412.

11. Kroppenstedt, R. M., E. Stackebrandt, and M. Goodfellow. 1990. Taxonomic revision of the actinomycete genera Actinomadura and Microtetraspora. Syst. Appl. Microbiol. 13:148-160.

12. Miyadoh, S., H. Anzai, S. Amano, and T. Shomura. 1989 Actinomadura malachitica and Microtetraspora viridis are synonyms, and should be transferred as Actinomadura viridis comb. nov. Int. J. Syst. Bacteriol. 39:152-158.

13. Nonomura, H. 1989. Genus Streptosporangium, p. 2545-2551. In S. T. Williams, M. E. Sharpe, and J. G. Holt (ed.), Bergey's manual of systematic bacteriology, vol. 4. The Williams \& Wilkins Co., Baltimore.

14. Ochi, K. 1989. Heterogeneity of ribosomal proteins among Streptomyces species and its application to identification. J. Gen. Microbiol. 135:2635-2642.

15. Ochi, K. 1992. Electrophoretic heterogeneity of ribosomal protein AT-L30 among actinomycete genera. Int. J. Syst. Bacteriol. 42:144-150.

16. Ochi, K., S. Miyadoh, and T. Tamura. 1991. Polyacrylamide gel electrophoresis analysis of ribosomal protein AT-L30 as a novel approach to actinomycete taxonomy: application to the genera Actinomadura and Microtetraspora. Int. J. Syst. Bacteriol. 41:234-239.

17. Ochi, K., and M. Yoshida. 1991. Polyacrylamide gel electrophoresis analysis of mycolateless wall chemotype IV actinomycetes. Int. J. Syst. Bacteriol, 41:402-405.

18. Ritter, E., and B. Wittmann-Liebold. 1975. The primary structure of protein L30 from Escherichia coli ribosomes. FEBS Lett. 60:153-155.

19. Shearer, M. C., P. L. Colman, and R. M. Ferrin. 1989. Genus Kibdelosporangium, p. 2590-2594. In S. T. Williams, M. E. Sharpe, and J. G. Holt (ed.), Bergey's manual of systematic bacteriology, vol. 4. The Williams \& Wilkins Co., Baltimore.

20. Shearer, M. C., A. J. Giovenella, S. F. Grappel, R. D. Hedde, R. J. Metha, Y. K. Oh, C. H. Pan, D. H. Pitkin, and L. J. Nisbet. 1986. Kibdelins, novel glycopeptide antibiotics. I. Discovery production, and biological evaluation. J. Antibiot. 39:1386-1394.

21. Wittmann-Liebold, B., A. K. E. Köpke, E. Arndt, W. Krömer T. Hatakeyama, and H. G. Wittmann. 1990. Sequence comparison and evolution of ribosomal proteins and their genes, $p$. 598-616. In W. E. Hill, A. Dahlberg, R. A. Garrett, P. B. Moore, D. Schlessinger, and J. R. Warner (ed.), The ribosome: structure, function, and evolution. American Society for Microbiology, Washington, D.C. 